\title{
Distribution of mineral species in different coal seams of Talcher coalfield and its transformation behavior at varying temperatures
}

\author{
Amit Banerjee $^{1}$ P. R. Mishra ${ }^{2}$ - Ashok Mohanty ${ }^{1} \cdot$ K. Chakravarty ${ }^{3}$. \\ R. Das Biswas ${ }^{1} \cdot$ R. Sahu ${ }^{2} \cdot$ S. Chakravarty ${ }^{1}$
}

Received: 27 August 2015/Revised: 28 February 2016/ Accepted: 18 March 2016/Published online: 2 June 2016

(C) The Author(s) 2016. This article is published with open access at Springerlink.com

\begin{abstract}
Mineral phase characterization and thorough understanding of its transformation behavior during combustion are imperative to know the potential utilization of coal in the thermal industries. The primary objective of this work is to analyze the quality of Indian Coals and obtain their mineral species-specific information at different depths. The samples were obtained from Talcher Coalfield, Odisha, India. Coal from four seam sections in the Talcher coalfield, India are mainly high ash coal (>50\%) and volatile matter deceases along with the seam depth. XRD results show that the major mineral phases present in the coal are quartz and kaolinite. Siderite, illite, and anatase were found in minor quantities. It has been observed that the clay minerals (kaolinite, silimanite, illite) decompose at higher temperature and traces of dolomite, mullite, hematite etc. are formed during the process of combustion. Among the four seams (M2, M12, M24 and M43) studied, ash of $\mathrm{M} 43$ has high $\mathrm{Al}_{2} \mathrm{O}_{3} \%, \mathrm{TiO}_{2} \%$ and $\mathrm{K}_{2} \mathrm{O} \%$ content and low $\mathrm{SiO}_{2} \%, \mathrm{CaO} \%$ and $\mathrm{MgO} \%$ content. High acidto-base ratios contributed to high ash fusion temperatures (IDT $>1500{ }^{\circ} \mathrm{C}$ ) and low slagging potential of the coals studied. Relatively low fouling index $(<0.3)$ was estimated for all the coal seams studied. Furthermore, thermodynamic modeling software, FactSage, have been used to envision the mineral phase transformations that take place between 800 and $1500{ }^{\circ} \mathrm{C}$ during coal combustion.
\end{abstract}

Keywords Proximate analysis $\cdot$ Ultimate analysis $\cdot$ FactSage $\cdot$ XRD $\cdot$ AFT $\cdot$ Talcher coalfield

\section{Introduction}

Power plants in India predominantly use coal as the energy source for power generation. Many problems associated with coal combustion, such as ash clinkering, slagging, fouling, agglomeration and deposition on heat exchange surfaces are routinely encountered in these power plants.

S. Chakravarty

sanchita@nmlindia.org

1 Analytical Chemistry Division, CSIR - National Metallurgical Laboratory, Jamshedpur, Jharkhand 831007, India

2 Department of Metallurgical and Materials Engineering, National Institute of Technology, Jamshedpur, Jharkhand 831014, India

3 R\&D, Tata Steel Ltd, Jamshedpur, Jharkhand 831007, India
Most thermal power industries generate database on elemental composition of coal ashes to predict the slagging and clinkering behavior of coal. However, only elemental compositions of coal ash cannot provide enough information on slagging characteristics of coal. Knowledge of structural characteristics of minerals and mineral phase transformation that occurs during the process of combustion of coal is essential to understand the slagging and clinkering behavior. There are a number of reports in the literature that provide information on the mineral matter association in coal (Van Dyk et al. 2009; Zhao et al. 2012; Dai et al. 2014a, b). Vassilev et al. (2005) have characterized mineral phase composition of composite samples from feed coals at Soma power station, Turkey. Mineral phases such as quartz, kaolinite, illite-muscovite, calcite, chlorite, plagioclase, pyrite etc. were identified in the feed coal at Soma power station, Turkey. Lopez and Ward (2008) have studied Combodian coal samples for 
mineralogy and kaolinite, illite, interstratified illite-smectite, quartz, and pyrite were the dominant mineral phases present in those coal samples. Recently, the process of phase transformation of mineral matter during coal combustion and gasification has been studied by some researchers. Chakravarty et al. (2015) have investigated the composition, mineral matter characteristics and ash fusion behavior of some Indian coals. FactSage thermodynamic model was used to understand ash fusion behavior and to predict the phase transformation that occurs during the process of coal combustion. Dai et al. $(2014 \mathrm{a}$, b) have studied origin of minerals and elements in the Late Permian coals, tonsteins, and host rocks of the Xinde Mine, Xuanwei, eastern Yunnan, China. Matjie et al. (2011) have investigated the mineral matter present in South African coal and their behavior in sintering and slagging of ash during the gasification process. The transformation behavior of mineral matters during combustion of Chinese coal gangue at varied temperature was studied by Zhou et al. (2012).

Indian Gondwana coals, in general, have high ash yields with low gross calorific value (Singh et al. 2013). In the commercial point of view, the coal quality in terms of fixed carbon content, composition and fusibility of coal ash are of prime importance. However, the fundamental concept of mineral matter transformation of high ash Indian coal during combustion requires a thorough investigation. The present study aims to investigate the mineral phase distribution at different seams of a particular borehole of Talcher coalfield, Odisha, India. Furthermore, the mineral phase transformation of coal at varying temperatures was also investigated experimentally and using the FactSage thermodynamic model.

\section{Materials and methods}

\subsection{Sampling}

Coal samples from a single borehole were collected from the Tentuloi Block, Talcher coalfield, Orissa, India. The coal bearing strata are made up of different coal seams as shown in Fig. 1. Coal samples used in the present study were from four different seams: seam No. M2 (depth: 154-155 m), M12 (depth: 241-296 m), M24 (depth: 337-341 m) and M43 (depth: 442-444 m). Coal samples were crushed and pulverized and passed through 212 microns mesh sieve size using a sieve shaker. The method of sampling and sample preparation for the chemical analysis was according to Indian Standard (IS: 436, 1964). Ashing of coal samples were done by heating at $750{ }^{\circ} \mathrm{C}$ in air for $1 \mathrm{~h}$ in a muffle furnace as per ASTM D3174-11. To study the mineral phase transformations at different

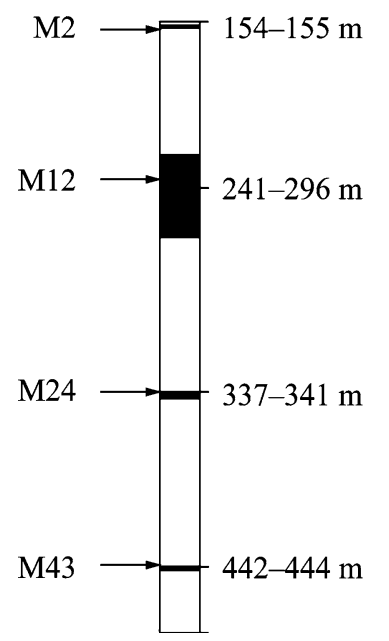

Fig. 1 Stratigraphy of the Tentuloi Block of Talcher coalfield, Odisha, India and its coal seam nomenclature

temperatures, coal samples were heat treated at 600 and $1000{ }^{\circ} \mathrm{C}$ in air for $1 \mathrm{~h}$ in a muffle furnace.

\subsection{Chemical characterization}

Proximate analysis of coal on air dry basis was carried out using TGA-1000 instrument (NAVAS, USA) as per ASTM D7582-10 procedure. NIST coal SRM 1632d was used as the reference material. Ultimate analysis of coal was performed using CHNS analyzer, Vario EL-III (Elementar GmBH, Germany) as per ASTM D5373-08 procedure. The instrument was calibrated using NIST coal SRM 1632d reference material. The gross calorific value was determined using Parr 6200 bomb calorimeter (Parr, USA) following ASTM D5865-10a procedure. Benzoic acid was used as the standard to calibrate the bomb calorimeter. Chemical analysis of major inorganic elements present in coal and its ash samples were carried out using X-ray fluorescence (XRF) spectrometer (Bruker, S8 TIGER). For XRF analysis, sample preparation was done by press pellet method in which $2 \mathrm{~g}$ of wax micro-powder (Merck make) was mixed with $8 \mathrm{~g}$ of coal or coal ash sample and pressed at 30 ton pressure to make the pellets. QuantExpress semi quantitative analysis software (Bruker) was used for data analysis.

\subsection{Mineralogical analysis}

Mineral matter characterization of coal, heat treated coal and its ash samples were performed by X-ray powder diffraction (XRD) instrument (D8 Discover, Bruker, Germany). Ni-filtered $\mathrm{CuK} \alpha$ was the radiation source and the scan was performed at $2 \theta$ range of $10^{\circ}-70^{\circ}$ at a scan rate of 
$2 \%$ min. HighScore Plus software package was used to identify mineral phases.

\subsection{Ash fusion temperature}

The ash fusion temperatures (AFT) of coal ashes were determined using AF 700 instrument (LECO, USA) under oxygen atmosphere in accordance with ASTM D1857 procedure. The procedure involves heating an ash cone up to $900{ }^{\circ} \mathrm{C}$ at $15^{\circ} \mathrm{C} / \mathrm{min}$ and then changing the heating rate to $5{ }^{\circ} \mathrm{C} / \mathrm{min}$ from 900 to $1500{ }^{\circ} \mathrm{C}$. During the process of AFT measurement, the initial deformation temperature (DT), softening temperature (ST), hemispherical temperature (HT) and fluid temperature (FT) were recorded according to the specific shape of the ash cone.

\subsection{Thermodynamic calculations}

Thermodynamic equilibrium calculation of coal ash in the oxidizing atmosphere was performed using FactSage software (version 6.4) to predict phase composition in the temperature range of $800-1500{ }^{\circ} \mathrm{C}$ at atmospheric pressure. Databases used for calculations were FactPS, ELEM, FTmisc, and FToxide. Elemental concentrations of coal ash were used as the input data for thermodynamic calculations.

\section{Results and discussion}

\subsection{Coal quality and mineralogy}

The quality of coal samples of 4 different seams M2, M12, M24 and M43 at varying depth of a particular borehole of Tentulai Block, Talcher coalfield were evaluated on the basis of the data obtained from proximate, ultimate and gross calorific value (GCV) analyses. The result (on air dry basis) is presented in Table 1. Coals of all the four seams are bituminous with reflectance of 0.51 and have ash yields in the range of $50.37 \%-58.53 \%$, fixed carbon content in the range of $20.57 \%-30.69 \%$ and GCV in the range of 2810-3179 cal/g. Among the four seams studied, coal of
M24 seam is of better quality having higher $\mathrm{FC}_{\mathrm{ad}}$ $(30.69 \%)$ and GCV (3179 cal/g). Coal at higher depth (M43 seam) was of relatively low quality having highest ash yields (58.53\%) and lowest GCV (2810 cal/g). Our earlier study also indicated that coal quality varied significantly from one seam to other for Indian coals (Chakravarty et al. 2015). It is also observed that $V_{\text {ad }}(\%)$ and $S_{\text {ad }}$ (\%) decrease with increase in depth.

Mineral species characterization provides detail understanding of mineral phases present in coal and also indicates the probability of slag formation and behavior of ash fusibility during combustion (Matjie et al. 2011). Coal samples of different seams were studied for mineral phase characterization using X-ray powder diffraction technique. The XRD diffractogram of M2, M12, M24 and M43 coal samples (Fig. 2) indicates that quartz and kaolinite are the major minerals present in all the four coals. Minor amounts of illite, siderite and anatase minerals were also observed in higher depth of 442-444 m (M43). The XRD diffractogram for all the four coal samples are very similar, suggesting that same minerals are present in different coal seams of Tentulai Block, Talcher coalfield.

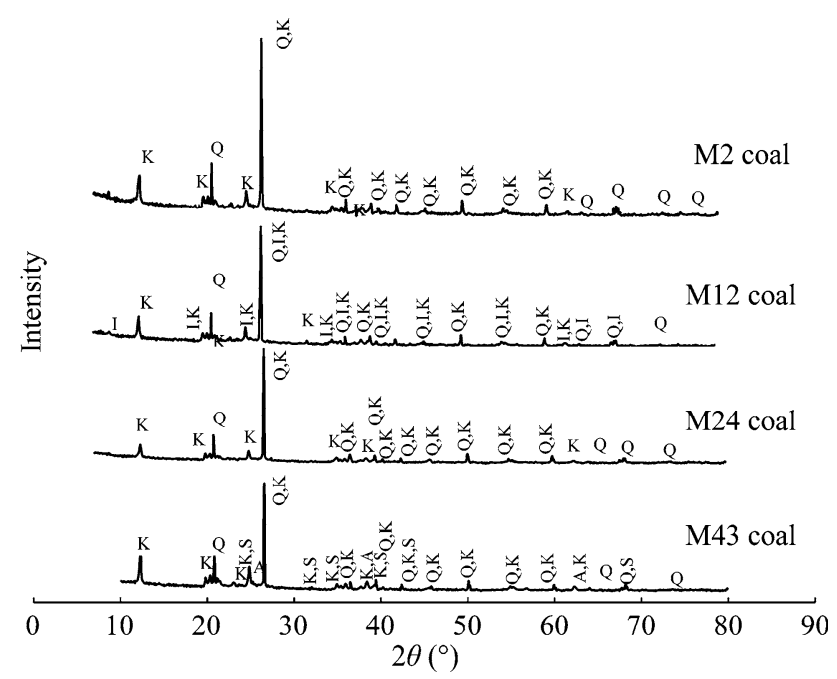

Fig. 2 XRD diffractograms of M2, M12, M24 and M43 coal samples (Q-quartz, K-kaolinite, I-illite, A-anatase, S-siderite)

Table 1 Proximate, ultimate and GCV analysis (air dry basis) of Talcher coals

\begin{tabular}{|c|c|c|c|c|c|c|c|c|}
\hline \multirow[t]{2}{*}{ Seam } & \multicolumn{3}{|c|}{ Proximate analysis $(\%)$} & \multicolumn{4}{|c|}{ Ultimate analysis (\%) } & \multirow{2}{*}{$\begin{array}{l}\mathrm{GCV} \\
\text { (cal/g }\end{array}$} \\
\hline & $A_{\text {ad }}$ & $V_{\text {ad }}$ & $\mathrm{FC}_{\mathrm{ad}}$ & $\mathrm{C}_{\mathrm{ad}}$ & $\mathrm{H}_{\mathrm{ad}}$ & $\mathrm{N}_{\mathrm{ad}}$ & $\mathrm{S}_{\mathrm{ad}}$ & \\
\hline M2 & 51.63 & 25.5 & 22.87 & 32.52 & 2.06 & 0.84 & 0.74 & 3114 \\
\hline M12 & 50.37 & 24.9 & 24.73 & 33.51 & 2.18 & 0.96 & 0.64 & 3107 \\
\hline M24 & 50.51 & 18.8 & 30.69 & 32.63 & 2.07 & 0.94 & 0.52 & 3179 \\
\hline M43 & 58.53 & 20.9 & 20.57 & 26.86 & 1.68 & 0.51 & 0.30 & 2810 \\
\hline
\end{tabular}


Table 2 Elemental composition of coal ash samples of Talcher coalfield (wt\%)

\begin{tabular}{llllllllll}
\hline Seam & $\mathrm{SiO}_{2}$ & $\mathrm{Al}_{2} \mathrm{O}_{3}$ & $\mathrm{Fe}_{2} \mathrm{O}_{3}$ & $\mathrm{CaO}$ & $\mathrm{MgO}$ & $\mathrm{MnO}$ & $\mathrm{TiO}_{2}$ & $\mathrm{Na}_{2} \mathrm{O}$ \\
\hline $\mathrm{M} 2$ & 69.6 & 22.6 & 1.8 & 1.3 & 0.7 & 0.01 & 1.3 & 0.22 & 0.45 \\
$\mathrm{M} 12$ & 66.9 & 24.8 & 2.4 & 1.0 & 0.5 & 0.02 & 1.5 & 0.26 \\
$\mathrm{M} 24$ & 70.7 & 23.6 & 1.2 & 0.2 & 0.5 & 0.01 & 1.3 & 0.29 & 0.39 \\
$\mathrm{M} 43$ & 62.1 & 31.2 & 2.4 & 0.2 & 0.3 & 0.03 & 2.0 & 0.19 & 0.52 \\
\hline
\end{tabular}

\subsection{Chemical composition of coal ash}

Chemical composition of coal ash is an indicator of mineral species present in coal samples and it can be also be used to predict slagging characteristics of coal. The chemical composition of ash samples for M2, M12, M24 and M43 coals was determined using $\mathrm{X}$-ray fluorescence spectrometer. The data are presented in Table 2. $\mathrm{SiO}_{2}$ and $\mathrm{Al}_{2} \mathrm{O}_{3}$ were the major constituents of coal ash, accounting to a total of $92 \%-94 \%$ of ash mass for all the four samples. The other constituents like trace amount of $\mathrm{Fe}_{2} \mathrm{O}_{3}(1.2 \%$ $2.4 \%), \mathrm{TiO}_{2}(1.3 \%-2.0 \%), \mathrm{CaO}(0.2 \%-1.3 \%), \mathrm{MgO}$ $(0.3 \%-0.7 \%), \mathrm{Na}_{2} \mathrm{O}(0.19 \%-0.29 \%)$ and $\mathrm{K}_{2} \mathrm{O}(0.38 \%-$ $0.52 \%)$ were also present. Overall, the chemical composition of all the four ash samples was similar with a slight variation of $\mathrm{SiO}_{2}$ content $(62.1 \%-70.7 \%)$. It is appeared from the Table 2 that the coal seam M43 is somewhat different from the other coal seam, M2, M12 and M24. The $\mathrm{SiO}_{2} \%, \mathrm{CaO} \%$ and $\mathrm{MgO} \%$ are lower whereas high concentrations of $\mathrm{Al}_{2} \mathrm{O}_{3}, \mathrm{~K}_{2} \mathrm{O}$ and $\mathrm{TiO}_{2}$ are present in coal seam M43 compared to the coal seam, M2, M12 and M24.

The fouling property of coal ash is predicted from the chemical composition of ash by calculating fouling index using formula:

Fouling index $=\left\{\left(\% \mathrm{Na}_{2} \mathrm{O}+0.6589 \times \% \mathrm{~K}_{2} \mathrm{O}\right) \times \%\right.$ ash $\} / 100$

From the value of fouling index, the fouling property of ash is predicted. Ash having fouling index value $<0.3$ has low fouling property, $0.3-0.45$ has medium fouling property, $0.45-0.6$ has high fouling property and $>0.6$ has severe fouling property. In the present case, fouling index of M2, M12, M24, and M43 coal ash samples are calculated to be $0.24,0.24,0.26$ and 0.30 , respectively. Therefore, it is expected that the coal from seams of M2, M12 and M24 will have low fouling property whereas marginal fouling will occur for coal seams of M43.

\subsection{Ash fusion temperatures}

Ash fusion temperatures help in identifying the slagging behavior of coal ash, which affects slag viscosity and refractory life. The main constituents of coal ash used in the present study are silica and alumina with small percentages of other oxides such as $\mathrm{Fe}_{2} \mathrm{O}_{3}, \mathrm{TiO}_{2}, \mathrm{CaO}$, $\mathrm{MgO}, \mathrm{K}_{2} \mathrm{O}$ and $\mathrm{Na}_{2} \mathrm{O}$. The ash fusibility is reported to be a function of these major oxides. Higher quantity of acidic compounds $\left(\mathrm{SiO}_{2}, \mathrm{Al}_{2} \mathrm{O}_{3}\right.$ and $\left.\mathrm{TiO}_{2}\right)$ in coal ash contributes towards higher melting point. On the other hand, basic compounds in coal ash $\left(\mathrm{Fe}_{2} \mathrm{O}_{3}, \mathrm{CaO}\right.$ and $\mathrm{MgO}, \mathrm{Na}_{2} \mathrm{O}$ and $\mathrm{K}_{2} \mathrm{O}$ ) have a fluxing effect on $\mathrm{SiO}_{2}$ and $\mathrm{Al}_{2} \mathrm{O}_{3}$, thereby reducing the fusion point of ash. Liu et al. (2013) have reported that three major chemical compositions that affect the AFTs of coal samples are $\mathrm{CaO}$, and $\mathrm{Fe}_{2} \mathrm{O}_{3}$ content and $\mathrm{SiO}_{2} / \mathrm{Al}_{2} \mathrm{O}_{3}$ ratio (S/A). AFTs decreases with increase of $\mathrm{CaO}$ and $\mathrm{Fe}_{2} \mathrm{O}_{3}$ content and increase of S/A ratio till 1.5. Beyond the S/A value of 2.0, AFTs decrease marginally or remain unchanged (Liu et al. 2013). In the present case, the S/A ratio of three samples are higher than $2.0(3.08,2.70$ and 2.99 for M2, M12, M24) respectively, and for M43, the $\mathrm{S} / \mathrm{A}$ value is 1.99 . Therefore the AFTs for all the coal samples are expected to be high. Furthermore, $\mathrm{Fe}_{2} \mathrm{O}_{3}$ and $\mathrm{CaO}$ content of all the four samples are low, ruling out the possibility of lowering of AFTs. Indeed, the AFTs of M2, M12, M24 and M43 coal ash samples determined experimentally using ash fusion determination instrument was found to be very high. The initial deformation temperature (IDT) for all the four ash samples were higher than $1500{ }^{\circ} \mathrm{C}$. The high AFT values are due to presence of high concentration of silica and alumina and appreciable amount of $\mathrm{TiO}_{2}$ whose melting temperatures range between 1685 and $1775{ }^{\circ} \mathrm{C}$ (Borio and Levasseur 1984). Therefore, coal of the four seams of Tentulai Block, Talcher coalfield is good for combustion with very little possibility of ash fusibility at fuel bed of the boiler.

\subsection{Phase transformation of mineral matter at high temperatures}

Mineral matter present in coal undergoes phase transformations at high temperatures during combustion. To understand the process of phase transformations, coal samples M2, M12, M24 and M43 were heated at two different temperatures of 600 and $1000{ }^{\circ} \mathrm{C}$ for $1 \mathrm{~h}$ each in a muffle furnace in air atmosphere. XRD analysis of the heat treated samples was then carried out to identify the mineral phases formed after heat treatment. Figures 3, 4, 5 and 6 


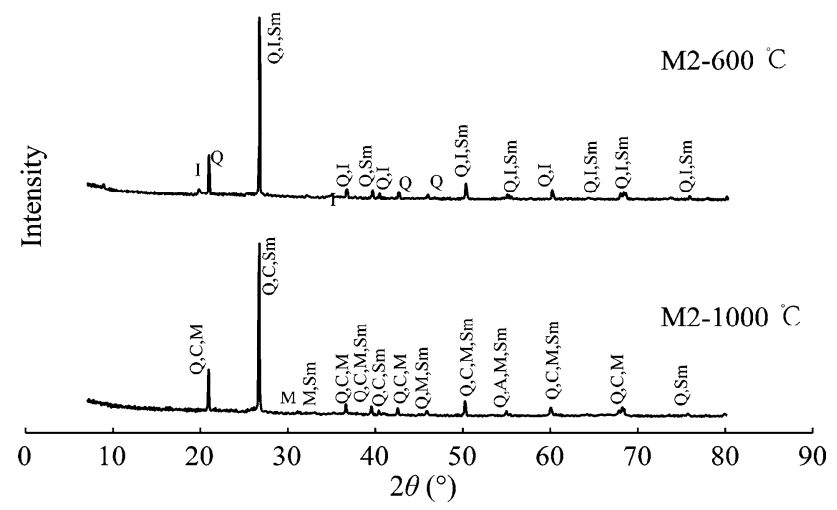

Fig. $3 \mathrm{XRD}$ diffractograms of M2 coal samples heat treated at 600 and $1000{ }^{\circ} \mathrm{C}\left(\mathrm{Q}\right.$ - quartz, $\mathrm{K}$-kaolinite, $\mathrm{I}-$ illite, $\mathrm{A}-\mathrm{AlPO}_{4}, \mathrm{Sm}-$ siliminite, $\mathrm{C}$-cristobalite, $\mathrm{M}-$ mullite)

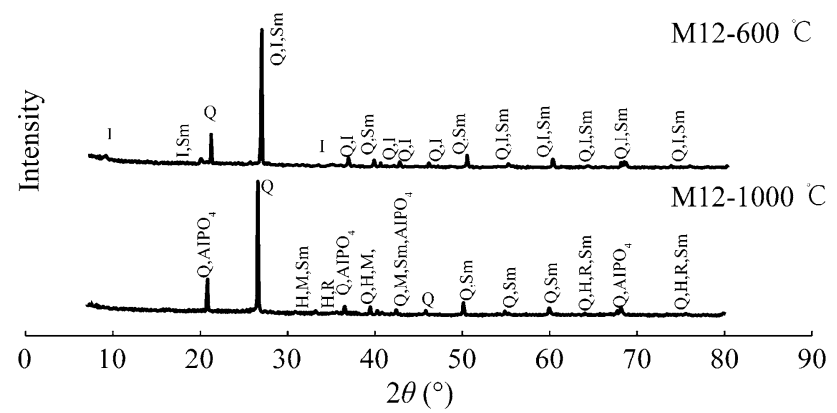

Fig. 4 XRD diffractograms of M12 coal samples heat treated at 600 and $1000{ }^{\circ} \mathrm{C}(\mathrm{Q}$ - quartz, $\mathrm{K}$ - kaolinite, I-illite, Sm-siliminite, $\mathrm{C}$ cristobalite, $\mathrm{M}$-mullite, $\mathrm{H}$-hematite)

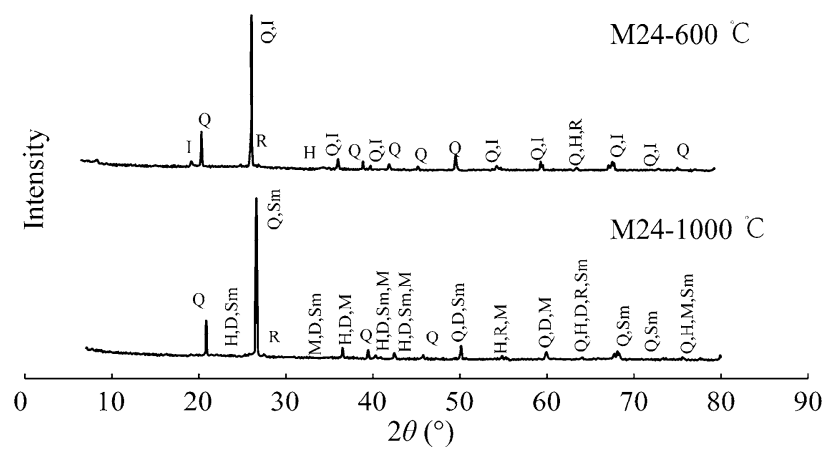

Fig. 5 XRD diffractograms of M24 coal samples heat treated at 600 and $1000{ }^{\circ} \mathrm{C}(\mathrm{Q}$ - quartz, $\mathrm{K}$-kaolinite, I-illite, Sm-siliminite, $\mathrm{C}$ cristobalite, $\mathrm{M}$-mullite, $\mathrm{H}$-hematite, $\mathrm{R}$-rutile, $\mathrm{D}$-dolomite)

represents XRD of heat treated coal samples of M2, M12, M24 and M43, respectively at two different temperatures. At higher temperature of 600 and $1000{ }^{\circ} \mathrm{C}$, a number of new phases are observed indicating that phase transformations of mineral matter have occurred during the heat treatment process. The kaolinite phase disappears and a new phase silimanite is formed at $600{ }^{\circ} \mathrm{C}$. The silimanite

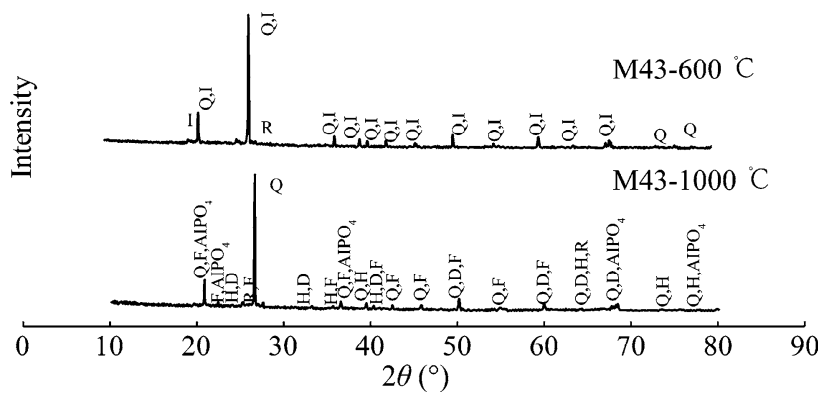

Fig. $6 \mathrm{XRD}$ diffractograms of M43 coal samples heat treated at 600 and $1000{ }^{\circ} \mathrm{C}(\mathrm{Q}$ - quartz, $\mathrm{K}$-kaolinite, I-illite, Sm—siliminite, $\mathrm{C}$ cristobalite, $\mathrm{M}$-mullite, $\mathrm{H}$-hematite, $\mathrm{R}$-rutile, $\mathrm{D}$ - dolomite, $\mathrm{F}-$ feldspar)

Table 3 Quantification of mineral species present in heat treated M2 coal samples $(\%)$

\begin{tabular}{lll}
\hline Minerals & $600{ }^{\circ} \mathrm{C}$ & $1000{ }^{\circ} \mathrm{C}$ \\
\hline Quartz & 43 & 78 \\
Kaolinite & - & - \\
Illite & 49 & - \\
Silimanite & 8 & 8 \\
Cristobalite & - & 3 \\
Mullite & - & 5 \\
AlPO $_{4}$ & - & 6 \\
\hline
\end{tabular}

Table 4 Quantification of mineral species present in heat treated M12 coal samples (\%)

\begin{tabular}{lll}
\hline Minerals & $600{ }^{\circ} \mathrm{C}$ & $1000{ }^{\circ} \mathrm{C}$ \\
\hline Quartz & 41 & 82 \\
Kaolinite & - & - \\
Illite & 54 & - \\
Silimanite & 5 & 6 \\
Hematite & - & 2 \\
Rutile & - & 1 \\
Mullite & - & 5 \\
AlPO $_{4}$ & - & 4 \\
\hline
\end{tabular}

Table 5 Quantification of mineral species present in heat treated M24 coal samples (\%)

\begin{tabular}{lll}
\hline Minerals & $600{ }^{\circ} \mathrm{C}$ & $1000{ }^{\circ} \mathrm{C}$ \\
\hline Quartz & 57 & 84 \\
Kaolinite & - & - \\
Illite & 42 & - \\
Silimanite & - & 7 \\
Hematite & - & 3 \\
Rutile & 1 & 1 \\
Mullite & - & 3 \\
Dolomite & - & 3 \\
\hline
\end{tabular}


phase is further transformed into cristobalite and mullite at $1000{ }^{\circ} \mathrm{C}$ as shown in Figs. 3, 4 and 5. Additionally, some new phases like hematite, dolomite, rutile $\mathrm{AlPO}_{4}$ and feldspar have also appeared for M24, M43 samples as observed in Figs. 5 and 6. HighScore Plus software was further utilized to quantify the mineral phases present in heat treated coal samples. The data for M2, M12, M24 and M43 coal samples are tabulated in Tables 3, 4, 5 and 6,

Table 6 Quantification of mineral species present in heat treated M43 coal samples (\%)

\begin{tabular}{lll}
\hline Minerals & $600{ }^{\circ} \mathrm{C}$ & $1000{ }^{\circ} \mathrm{C}$ \\
\hline Quartz & 34 & 78 \\
Kaolinite & - & - \\
Illite & 65 & - \\
Lizardite & - & - \\
Hematite & - & 3 \\
Feldspar & 1 & 10 \\
AlPO $_{4}$ & - & 4 \\
Dolomite & - & 3 \\
\hline
\end{tabular}
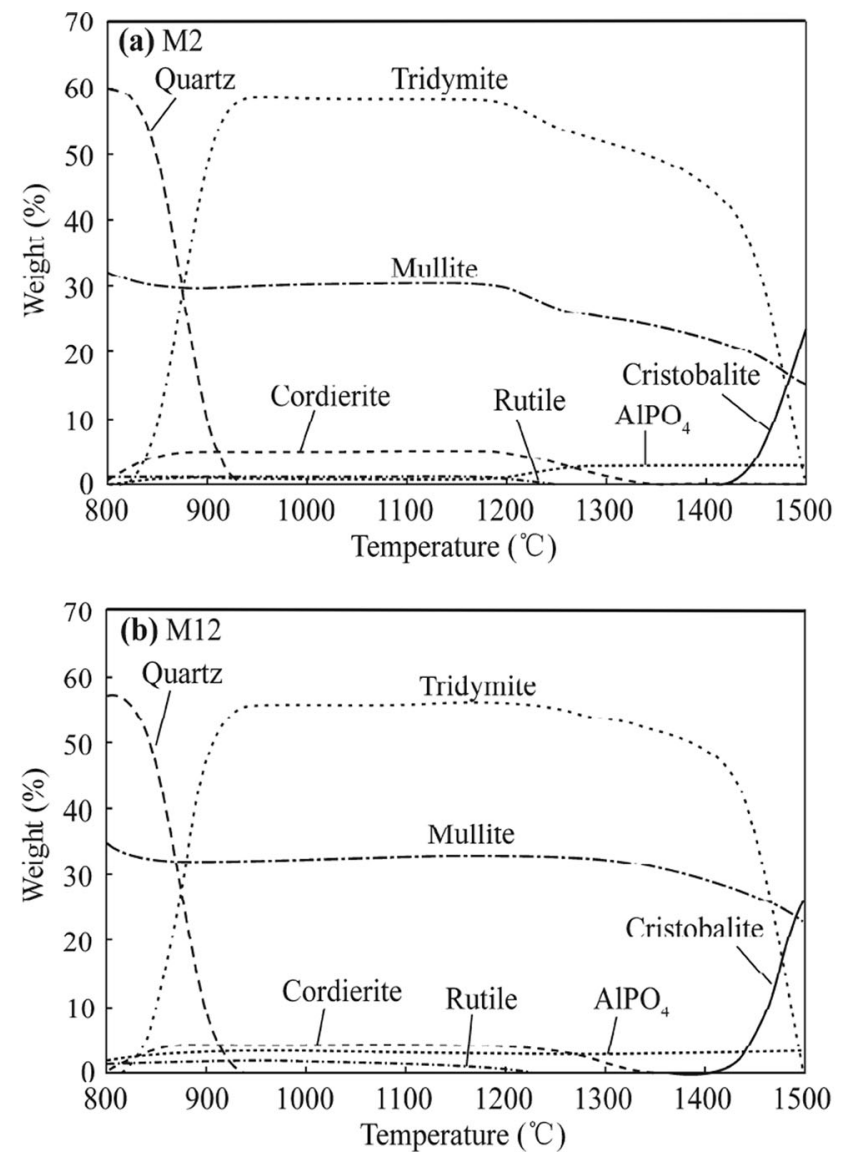

respectively. Quantitative estimation of mineral phases shows that all the clay minerals and aluminosilicates disappeared at high temperature $\left(1000{ }^{\circ} \mathrm{C}\right)$, leaving behind $\mathrm{SiO}_{2}(78 \%-84 \%)$ as the major phase along with other trace minerals as shown in Tables 3, 4, 5 and 6. Similar phase transformations have been reported in the literature (Pan et al. 2000; Bhargava et al. 2009).

\subsection{FactSage thermodynamic modeling}

FactSage 6.4 thermochemical software and databases computer package was used in order to predict (1) the chemical composition of coal ash at equilibrium during combustion (2) simulation of mineral phase transformation from 800 to $1500{ }^{\circ} \mathrm{C}$, and (3) the relationship between mineral phases and ash fusibility. Chemical analysis data of ash samples was used as the input for the FactSage calculations.

FactSage was first used to predict the mineral phase transformations that might occur at equilibrated conditions from 800 to $1500{ }^{\circ} \mathrm{C}$ for M2, M12, M24 and M43 coal ash samples. The results are presented in Fig. 7. Figure 7a shows that quartz and mullite will be predominantly
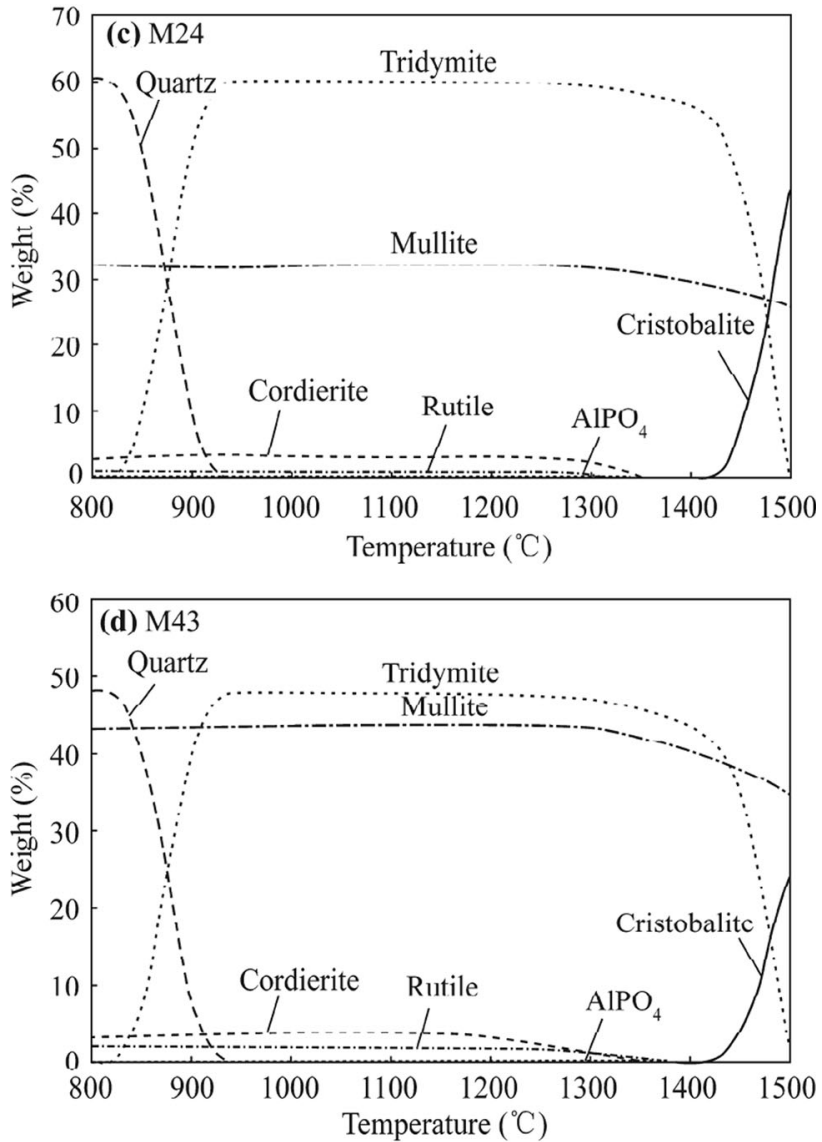

Fig. 7 Phase transformation of coal ash sample obtained using FactSage 
formed at $800{ }^{\circ} \mathrm{C}$ in $\mathrm{M} 2$ coal ash sample. The major phase quartz remains till $850^{\circ} \mathrm{C}$, thereafter undergoes polymorphism and forms tridymite at higher temperatures. Aluminium phosphate $\left(\mathrm{AlPO}_{4}\right)$ and cristobalite $\left(\mathrm{SiO}_{2}\right)$ phase starts forming after 1100 and $1450{ }^{\circ} \mathrm{C}$, respectively. The mineral phases predicted using FactSage agrees well with XRD result of M2 coal ash (Fig. 3). Figure 7b-d show a similar phase conversion trend for coal ashes of M12, M24 and M43, respectively. Rutile and cordierite present in low amounts for all the studied coal ash samples completely disappear after 1250 and $1350{ }^{\circ} \mathrm{C}$, respectively. There are minor variations in composition between XRD and FactSage results as it is quite obvious that the FactSage predicts the stable mineral phases as a function of temperature whereas the mineral phases indicated by XRD analysis are the transient phases at varying temperature.

\section{Conclusions}

Investigations carried out on the coal samples of four different seams of a single borehole of the Tentuloi Block, Talcher coalfield, Orissa, India reveals that coals of all the four seams are similar in nature having high ash yields and low calorific values. The coal quality (FC content, GCV value) decreases marginally for the seam at higher depth. Mineral matter composition of the coal ash for the four coal seams were similar with $\mathrm{SiO}_{2}$ and $\mathrm{Al}_{2} \mathrm{O}_{3}$ jointly accounting to a total of $92 \%-94 \%$ of ash mass. The coal ash composition in terms of major components, $\mathrm{SiO}_{2}, \mathrm{Al}_{2} \mathrm{O}_{3}, \mathrm{CaO}$, $\mathrm{TiO}_{2}, \mathrm{~K}_{2} \mathrm{O}$ and $\mathrm{Fe}_{2} \mathrm{O}_{3}$ however varied considerably between the seam M43 and other three seams, M2, M12 and M24. AFTs of coal ashes of all the four coal seams were very high with IDT greater than $1500{ }^{\circ} \mathrm{C}$. Therefore, it indicates that coal of the four seams of Tentulai Block, Talcher coalfield is good for combustion with very little possibility of ash fusibility. Heat treatment studies of coal samples at different temperatures indicate that the mineral matter present in coal samples get transformed to different phases at different temperatures. New phases like hematite, rutile, mullite and $\mathrm{AlPO}_{4}$ were formed at $1000{ }^{\circ} \mathrm{C}$. Finally, FactSage thermodynamic modeling studies were carried to corroborate the findings of heat treatment experiments. FactSage predictions and experimental results agree well regarding phase transformation of mineral maters during heat treatment process.

Acknowledgments The authors acknowledge and extend their sincere gratitude to the significant contribution and financial support provided by Dr. S. Srikanth, director of CSIR - National Metallurgical Laboratory, Jamshedpur, India.
Open Access This article is distributed under the terms of the Creative Commons Attribution 4.0 International License (http://crea tivecommons.org/licenses/by/4.0/), which permits unrestricted use, distribution, and reproduction in any medium, provided you give appropriate credit to the original author(s) and the source, provide a link to the Creative Commons license, and indicate if changes were made.

\section{References}

Bhargava S, Garg A, Subasinghe N (2009) Insitu high-temperature phase transformation studies on pyrite. Fuel 88(1):988-993

Borio R, Levasseur A (1984) Overview of coal ash deposition in boilers. Energy Fuel 29(4):193-203

Chakravarty S, Mohanty A, Banerjee A, Tripathy R, Mandal GK, Basariya R, Sharma M (2015) Composition, mineral matter characteristics and ash fusion behavior of some Indian coal. Fuel 150:96-101

Dai S, Li T, Seredin VV, Ward CR, Hower JC, Zhou Y, Zhang M, Song X, Song W, Zhao C (2014a) Origin of minerals and elements in the Late Permian coals, tonsteins, and host rocks of the Xinde Mine, Xuanwei, eastern Yunnan, China. Int J Coal Geol 121:53-78

Dai S, Seredin VV, Ward CR, Jiang J, Hower JC, Song X, Jiang Y, Wang X, Gornostaeva T, Li X, Liu H, Zhao L, Zhao C (2014b) Composition and modes of occurrence of minerals and elements in coal combustion products derived from high-Ge coals. Int $\mathbf{J}$ Coal Geol 121:79-97

Liu B, He Q, Jiang Z, Xu R, Hu B (2013) Relationship between coal ash composition and ash fusion temperatures. Fuel 105:293-300

Lopez IC, Ward CR (2008) Composition and mode of occurrence of mineral matter in some Colombian coals. Int $\mathrm{J}$ Coal Geol 73(1):3-18

Matjie RH, French D, Ward CR, Pistorius PC, Li Z (2011) Behaviour of coal mineral matter in sintering and slagging of ash during the gasification process. Fuel Process Technol 92(8):1426-1433

Pan Y, Zhu RX, Banarjee SK, Gill J, Williams Q (2000) Papers on geomagnetism and paleomagnetism marine geology and geophysics-rock magnetic properties related to thermal treatment of siderite: behavior and interpretation. $J$ Geophys Res 105(1):783-794

Singh PK, Singh GP, Singh MP, Naik AS (2013) Petrology of coals from Rampur Seam-IV and Lajkura seam, Ib River coalfield, Mahanadi Valley, Orissa, India. Energy Sources A Recovery Util Environ Eff Taylor Fr 35:1681-1690

Van Dyk JC, Benson SA, Laumb ML, Waonnders B (2009) Coal and coal ash characteristics to understand mineral transformations and slag formation. Fuel 88(1):1057-1063

Vassilev SV, Vassileva CG, Karayigit AI, Bulut Y, Alastuey A, Querol X (2005) Phase-mineral and chemical composition of composite samples from feed coals, bottom ashes and fly ashes at Soma Power Station Turkey. Int J Coal Geol 61(1):35-63

Zhao Y, Zhong J, Zheng C (2012) Transformation of aluminium rich minerals during combustion of a bauscite-bearing Chinese coal. Int J Coal Geol 94(1):182-190

Zhou C, Liu G, Yan Z, Fang T, Wang R (2012) Transformation behavior of mineral composition and trace elements during coal gangue combustion. Fuel 97(1):644-650 